Journal

of Geography,

Politics and Society

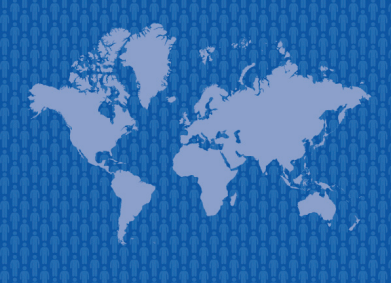

$10(4) / 2020$

\section{Journal of Geography, Politics and Society}

2020, 10(4), 8-16

https://doi.org/10.26881/jpgs.2020.4.02

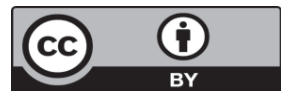

\title{
DECOMMUNIZATION OF URBAN TOPONYMY IN UKRAINE: CAUSES AND CONSEQUENCES
}

\author{
Aleksander Kuczabski (1), Alina Boychuk (2) \\ (1) Department of Regional Development, University of Gdańsk, Bażyńskiego 4, 80-309 Gdańsk, Poland, ORCID: 0000-0003-1271-0782 \\ e-mail: aleksander.kuczabski@ug.edu.pl (corresponding author) \\ (2) European Business Association Western Ukrainian Office, Kulparkivska 200a, 79071 Lviv, Ukraine. \\ e-mail: alinalv19@gmail.com
}

\section{Citation}

Kuczabski A., Boychuk A., 2020, Decommunization of urban toponymy in Ukraine: causes and consequences, Journal of Geography, Politics and Society, 10(4), 8-16.

\begin{abstract}
The decommunization in Ukraine took place differently than in other post-communist countries. For many years after the collapse of the USSR, Ukrainian society tolerated the post-communist remnants. The conflict with Russia has fundamentally changed the narrative in relation to historical memory. Through the active toponymic policy of the central government in 2014-2016, it was possible to get rid of almost all communist symbols and names in public space. Nevertheless, a retreat in the matter of commemoration cannot be ruled out, as left-wing, and sometimes even pro-communist, views remain popular among a large part of the Ukrainian society.
\end{abstract}

\section{Key words}

decommunization, urban toponymy, historical memory, toponymic politics, Ukraine.

\section{Introduction}

The establishment and consolidation of the communist ideology in European countries was usually associated with the geopolitical expansion of the USSR (1922-1991). Despite numerous supporters of the communist model, military and police coercion was the main lever of its spread. Overall, there were two major waves of communization (sovietization) in Europe. The first one covered the area that came under the rule of communist Moscow as a consequence of the civil war (the early 1920s), while the second one affected the states and territories occupied by the USSR during World War II (1945).

The deep socio-economic and later political crisis in the USSR led to the marginalization of the communist ideology, which did not enjoy public support without the use of military and police force. With the collapse of the USSR (1990-1991), all post-communist countries of Central Europe, and partly also Eastern Europe, implemented a strategy of democratization, abandoning totalitarian practices and displacing pro-communist elites from various spheres of social and political life (see: Âz'kovij (ed.), 2007; Łukowski, Wojtaszczyk (eds.), 1996). 
The post-communist transformation in the postSoviet space proceeded in different ways: some countries quickly and irreversibly switched to democratic principles (the Czech Republic, Estonia, etc.); others, while maintaining the general democratic vector of development, experienced many relapses of recommunization (Bulgaria, Moldova), and still others clearly returned to totalitarian practices (Russia, Belarus) (see: Milczarek, Nowak (eds.), 2003; Orlova, 2010). Ukraine, unlike other countries in the region, has shown a much longer and more dramatic transition from totalitarianism to democracy. Moreover, this process was not linear and was characterized by frequent changes of the transition phases (Avioutskii, 2006; Kuczabski, Michalski, 2014).

This article presents the process of decommunization based on the example of Ukraine. The specific subject of interest is the last wave of decommunization of the urban toponymy, which occurred in 2014-2019. The basic concepts and terms characterizing toponymic policy are reviewed, and the essence and causes of decommunization, especially its "last" wave, are analyzed. Moreover, the current legal mechanisms for implementing the remembrance policy in the urban landscape are shown.

\section{Basic features of the toponymic decommunization policy}

Toponymic policy reflects social demands and expectations regarding the shaping of symbolic space, including names of geographical sites (toponyms). The key players in the process of filling the geographical space semantically are, on the one hand, political forces as the creator of toponymic information, and on the other hand - the population as its recipient. Political forces willingly use geographical space to promote their own ideological markers. In turn, the society may accept or ignore these markers, trying to create its own, alternative toponymic dimension. As a result, in order to implement an effective toponymic policy, it is insufficient to have legal or police mechanisms to create toponymic nomenclature; it is necessary to recognize and feel the public demand for it.

Public expectations of a toponymic policy of remembrance are based on the collective historical memory of a state, region, ethnic group, etc. On the other hand, historical memory "constitutes the basis of identity, gives national communities a sense of cultural exclusivity and a shared historical fate" (Gurik, 2016, p. 26). In this context, toponymic politics can be passive - reflecting the existing traditional images of collective historical memory, or active - removing unwanted symbols from the public space, promoting or imposing new ideological content. According to M. Dymnicka and J. Szczepański (2016), the policy of remembrance covers all conscious and unconscious, intentional and contingent actions, and is part of various identity projects, which, apart from the properties characteristic of the city, also include the residents' attachment to the way they live in it, local customs or cultural landscape.

Historical memory is not unique, unambiguous and immutable. V. Ciba (2017, p. 164), describing the national culture of commemoration, speaks of "generational communication codes for describing the past". In general, historical memory can be more or less stable (ingrained in the mind), structured (depending on the social group), variable (susceptible to influence), and so on. Geographical name changes, including changes to street and square names, are related to political and organizational changes in the state.

The city space is an exemplary arena for reproduction, affirmation or creation of historical memory. In a country, each city is characterized by both common general features of reflecting historical memory and a specific local context or color. According to S. Vodotik and L. Savenok (2017), cities have their own culture of memory. The most common, effective and efficient measure of the remembrance policy is giving various geographical sites the names of iconic figures (patrons) or events and places important from the point of view of political necessity.

Street names not only help one to find one's bearing and identify places, but they also preserve in the minds of residents certain events, people or phenomena they commemorate. Therefore, they are of great importance for every authority, because they refer to a specific symbolism hidden behind given persons or events. In addition to their purely practical function, the names also contain a deeper message; they are the carrier of specific historical, cultural and social content, as well as the image of a given time (Kędziora, 2012; Wagińska-Marzec, 2017).

The practice of using commemorative names dates back to the second half of the 19th century, so it is a relatively young tradition (Kita, Nartonowicz-Kot, 2012). Such names may be imposed by the authorities or are the result of the demands of society to manifest its attitude to the present as well as to the past. Due to the turbulent history of the nation, street names are often changed many times in different historical periods, and the most common reason for these changes is political and ideological considerations (Wagińska-Marzec, 2017).

Street naming becomes a certain mirror reflecting the face of a given historical period in a given 
country. As a result, the more frequently the names of streets are changed in it, the more turbulent its history is (Jankowska, 2013). Renaming streets during the political breakthrough expresses the competition for the way of classifying reality, evaluating history and creating the state's identity (Hałas, 2004).

Changing street names is a process that affects ordinary people extremely strongly; it is an integral part of their daily lives, so it raises considerable interest of the general public and is present in public discussion. They are also often controversial. Renaming streets is usually a political act in which the authority of the state and its monopoly on the interpretation of history are manifested. In the process of assigning specific political meanings to the streets, the predominant, though not exclusive, group are names that refer to specific figures or collective heroes, such as armed or political groups (Różycki, 2018, 2019).

Street names can become entangled in the politics of defining what is historically important or worthy of public memory. They are also part of a larger struggle for social and political identity, and are used both to oppose the hegemonic order and to recreate it (Alderman, 2002). Street names are changed in this context to promote in the public awareness specific events, characters and organizations that appear in the street names, but also to erase from the public awareness other events, characters and organizations that are removed from street names (see: Rose-Redwood, 2008; Różycki, 2019).

If the past is the main source of historical memory, its drama determines the essence and structure of historical memory. As M. Gurik (2016, p. 26) notes, "The problem of preserving and recreating historical memory is particularly acute in post-totalitarian societies that experienced collective historical trauma in a state of colonial dependence."

For the countries of Eastern Europe, the problem of historical memory is still closely related to the period of the communist model of commemorating (sovietizing) public space. The imposition of communist ideological symbols by artificially shaping a new historical memory was a common feature of communism in various national communities.

The difference between countries, regions and cities was the duration and the scale of sovietization, the brutality of its planting, and the local specificity of the commemorative semantic area. Identification primarily with communist Russia (the Kremlin) is an important feature of sovietization in European countries (with the small exception of Albania and Yugoslavia). In fact, the spread of communist commemorative markers served to underline Moscow's geopolitical dominance. That is why communization is often equated with external enslavement.
The toponymic policy of the last three decades in the vast majority of Central and Eastern European countries can be described as being part of decommunization. Communist ideology, which for a long time dominated the sphere of geopolitical influence of the USSR, left behind a whole layer of symbolism, which at the turn of the 1980s and 1990s lost its relevance to the new socio-political context, including toponymy. The system of activities aimed at liberating oneself from the influences and consequences of the communist ideology in all spheres of life is referred to as decommunization (Droguševs'ka, 2017; Kiridon, 2017).

Decommunization has various dimensions: from existential (abandoning the communist worldview), economic (returning to a market economy with private ownership), political (introducing political competition through democratic mechanisms) to formal (cleansing the information field from obsolete commemorative markers that may be associated with the communist past). As M. Czepczyński (2008) notes, the reconstruction of the civic significance of urban space is among the most important tasks facing post-socialist societies.

At the legislative level, the decommunization process covers the following areas: vetting of former functionaries of the communist regime, condemnation of the communist regime and its criminal practices, honoring the heroes who fought against the communist regime and restoring the rights of its victims, making available archival documents of communist secret services (Râbenko, Kogut, 2017).

Matching formal decommunization to the actual social expectations requires consistency and synchronicity. Introducing formal decommunization by force can provoke denial and even resistance and conflicts. In the context of formal decommunization, A. Gricak (2016) noted that "it creates the illusion that history can be overcome by interpreting historical memory, but that history is interpreted not through memory but through political reforms."

\section{The essence of decommunization and the causes of its new wave in Ukraine}

Toponymic decommunization is a reaction to changes that took place in the ideological landscape of the geographical space of many European countries during the period of domination and cultivation of the communist worldview there. In order to understand the essence of decommunization, it is necessary to analyze how sovietization took place, how deep it was and how it influenced the shaping of actual historical memory. 
The main common features of toponymic sovietization were its enormous scale, brutality of introduction, and temporal instability. The scale manifested itself in the communist authorities' efforts to change completely the informational content of geographical space. As part of sovietization, firstly the toponyms related to ideologically hostile worldview systems were replaced: the world of religion, other (and therefore hostile) forms of power and government (from the Russian tsar to bourgeois democracy), national patriotic worldview (as opposed to the concept of internationalism), and so on.

Ideologically neutral names that did not fit the ideologized communist way of life were also under constant threat. As noted by İ. Staren'kij and Â. Zajšlûk (2017, p. 113), using the example of sovietization in Kamieniec Podolski, the Bolshevik government "tried to erase from historical memory everything that could resemble the previous days, incl. by brutally interfering with the city's toponymy, imposing names related to revolutionary events". In total, about 200 new names were created in Kamieniec Podolski during the Soviet period ( $42.5 \%$ of all toponyms), which were very rarely associated with the history of Ukraine and its heroes (Staren'kij, Zajšlûk, 2017, p. 114).

Sovietization was implemented through a strictly hierarchical set of names, titles, and symbols that were usually reproduced mindlessly, spontaneously and almost without taking into account local specificities. The hierarchical feature of the communist pantheon was emphasized by L. Males (2016, p. 66), noting in the urban toponymy the names of revolutionaries of the "first, then second and subsequent order". Depending on the area, the general pantheon of communist figures and events was sometimes supplemented with local names.

It should also be noted that the toponymic pantheon significantly evolved during the domination of the communist ideology. The reformatting consisted in the successive replacement of certain persons and events with others or changing their place in the overall hierarchy. Nevertheless, the figure of Lenin was invariably the central figure of the communist pantheon of the USSR and the satellite states since 1924. His importance in the shaping and content of geographical space is special and unique. As aptly noted by K. Kobčenko (2016, p. 67), the monuments of Lenin are "markers in the mental mapping of Ukrainians, specific 'milestones' that marked the symbolic boundaries of (post)Soviet space".

Constant changes in the communist pantheon had a significant impact on the nature of the toponymic politics of the time: often the existing communist toponyms were replaced with new ones, creating chaos and distrust as to the stability of geographical names. Hence, the first examples of decommunization can be found directly in the communist period and were associated with the shedding of successive communist leaders: Trotsky, Stalin, Molotov, Khrushchev and hundreds of other smaller figures discredited during the internal political struggle. However, the removal of some persons from the information space was accompanied by the emergence of others with the same ideological profile.

Since in the European geopolitical direction Russia was the source of the spread of the communist ideology, sovietization was simultaneously perceived as a strictly Russian product in all the conquered countries. Thus, the entire layer of communist ideology, reflected in the toponymy, was characterized by a clearly defined Russian color. M. Râbčuk (2016) points out that in Ukraine communism was in fact a cover for Russian imperial hegemony.

In Ukraine, in this context, the situation was additionally complicated by the fact that sovietization there "overlapped with the strong results of the previous 250-year russification" (Kiridon, 2017, p. 157). In general, the communist era in the context of Ukraine is often perceived as a continuation of the cultivation of the Russian imperialist ideology, which was essentially anti-Ukrainian (Râbčuk, 2016; Kobčenko, 2016).

The first wave of real decommunization took place in the last years of the USSR. This meant a change in the ideological orientation of the population, and it was manifested in acts of mass, deliberate rejection of the devalued ideology. According to T. Hitrov (2015), the shaping and segmentation of the "decommunization" discourse is related to the information activities of Ukrainian social movements and organizations, in particular the People's Movement of Ukraine, the Commemorative Society, the Ukrainian Helsinki Union and others. According to V. Ciba (2017, p. 153), the first stage of the "deconstruction of the Soviet historical heritage" dates back to the period of perestroika, when the local governments of Donetsk and Lugansk initiated the renaming of Zhdanov to Mariupol, and Voroshilovgrad to Luhansk, respectively in 1989 and 1990.

Similar trends occurred in urban toponymy, but they were usually uncommon and selective. The first renaming of streets and squares in Ukrainian cities concerned their central, historical, and representative parts (see: Males, 2016; Staren'kij, Zajšlûk, 2017). They were mainly related the returning to the old (historical) names.

Immediately after the fall of communism, there were clear regional differences and disproportions in the processes of decommunization in Ukraine. While 
the local authorities of Galicia and partially of Volhynia were willing to support the initiatives of rightwing parties and social organizations in the face of changes in the historical and cultural landscape, outside these regions, de-sovietization was slow and without enthusiasm from the public. Almost the entire 1990s were characterized by a powerful electoral triumph of left-wing forces, as well as President Leonid Kuchma's intention to pursue a policy of careful political maneuvering (Ciba, 2017).

In the first period, just after the fall of communism, street names were de-communized in Ukraine according to the wishes or at least with the consent of the inhabitants. Thus, if the name of the street was not changed immediately, then there was no chance for such a change later. On the one hand, the inhabitants got used to the existing old name even more; on the other hand, although the name could be associated with the communist period, it did not necessarily reflect its criminal nature, especially that all the controversial names were already changed in the first phase of decommunization.

Additionally, it should be noted that renaming streets and squares is usually quite costly and burdensome. These costs are borne not only by local governments, but also directly by the inhabitants who have to exchange documents, information boards or advertising banners. In such a situation, the troublesome economic crisis of the 1990s and the lack of adequate resources at the disposal of local governments discouraged them from taking initiatives related to the deliberate and large-scale changes of the old communist names.

In Ukraine, Leonid Kravchuk (1992), Leonid Kuchma (2001) and Viktor Yushchenko (2007) attempted to revive the waning decommunization at the presidential level. However, such initiatives were usually not based on any effective legal mechanisms (Râbčuk, 2016). During Yushchenko's presidency, another attempt at decommunization was associated with the policy of bringing attention to the Holodomor tragedy, which was explained as a consequence of the deliberate policy of the communist authorities at the time. For this purpose, it was particularly important to pass the Law of Ukraine "On the Holodomor of 1932-1933 in Ukraine" in 2006, which provided a legal basis for the demolition of monuments to the Bolsheviks considered to be the perpetrators of the famine in Ukraine (see: Ciba, 2017).

The Revolution of Dignity and the Russian aggression against Ukraine in 2013-2014 became a powerful catalyst for the last wave of decommunization. Among others, the reason lied in the similarities that were easy to find between the partially forgotten totalitarian communist past of Ukraine and the Russian propaganda of that time. According to V. Ciba (2017, p. 152), "an important aspect of the policy of 'decommunization' was to be ... quickly dissociating oneself from the practices of commemoration common with Russia". Russian aggression revived the aspects of Ukrainian collective memory related to the ideas of national solidarity, sacrifice, patriotism and armed resistance to the aggressor (Râbčuk, 2016). In addition, new challenges and events in Ukraine have created a need to perpetuate and commemorate "the memory of the dead, heroes, new symbols and social phenomena (volunteering, volunteer battalions)" (Males, 2016, p. 63).

Significant accumulation of the former communist content in Ukrainian public space began to be perceived as an obstacle to European integration and mobilization against Russian aggression. A. Kiridon (2017) pointed out that Sovietism did not leave independent Ukraine, but it actively exists among Ukrainians and remains deeply rooted in social consciousness. Cleansing Ukraine of the symbols of communism began spontaneously, enthusiastically and massively. V. Ciba (2017) claims that the demolition of Lenin's statue in Kiev on 8 December, 2013, during the Euromaidan, by representatives of the All-Ukrainian Union "Svoboda", was the driving force of the present "decommunization", the fourth stage of de-sovietization. Later, the process became massive, because in 2014 alone, more than 500 monuments to Lenin were dismantled in various cities of Ukraine (Pìd čas "lenìnopadu" ..., 2014).

\section{The current legal regulation and practice of decommunizing urban toponymy in Ukraine}

Spontaneous decommunization gained legal framework in Ukraine only on 9 April, 2015, when the Law "On Condemnation of Communist and National Socialist (Nazi) Totalitarian Regimes and Prohibition of Propaganda of Their Symbols" (Zakon Ukraïni ..., 2015) was passed. This act gave decommunization the status of a state policy and regulated the forced change of names referring to the post-communist legacy. This concerned geographical names, toponymic sites (streets, avenues, squares, etc.), legal entities, press titles, names of trademarks and services. The necessity to liquidate monuments, statues, commemorative plaques and other memorabilia of a communist character was also taken into account. The government's intentions to finally get rid of the traces of the communist past were based on severe sanctions for non-compliance or breaking the law in this regard. According to A. Kozyrska (2016), the 
new politics of memory had to favor the overcoming of the Soviet legacy in mentality, historical myths and stereotypes that inhibited the consolidation of Ukrainian society.

The law gave local governments up to six months to rename all localities and toponymic sites that contained symbols of the communist totalitarian regime. These were city districts, squares, boulevards, streets, avenues, driveways, passages, alleys, malls, embankments, bridges, and so on. It was assumed that if the local government's legislative body failed to make a decision to change the appropriate name within the prescribed period, the task related to the change would be taken over by the competent head of the municipality or the mayor, who in turn had a three-month deadline for it. If decommunization was not completed in that case, the law transferred this responsibility to the heads of regional state administrations, giving them another three months to do so. Moreover, the act required local authorities to follow the recommendations of the Ukrainian Institute of National Memory with regard to the interpretation of the relevant names.

The "last" wave of decommunization in Ukraine was not received by society in an unambiguously positive way (see: Filon, Borsuk, 2018; Mälksoo, 2018). The flaw of implementing decommunization was the imposition on local governments of a government model of historical memory, an uncompromising change of names and shifting the relevant expenses to local budgets, enterprises and citizens. The policy of decommunization often resulted in more or less active resistance from its opponents. However, it should be noted that this resistance did not take an organized form and was generally within the law (though at times it went beyond ethics and respect for opponents).

Even in a rather brutal and dynamic form, decommunization did not cause any mass opposition in Ukraine (Kozyrska, 2016). Most often, decommunization was opposed through the courts. The most prominent act in Ukraine in this respect was the submission of an appeal on 30 May 2017 to the Constitutional Court by 46 Ukrainian MPs of the Act "On Condemnation of Communist and National Socialist (Nazi) Totalitarian Regimes and Prohibition of Propaganda of Their Symbols" on the compliance with the Constitution (Konstitucijne podannâ). Nevertheless, on 16 July 2019, the Constitutional Court confirmed the constitutionality of this act.

The issue of individual renaming was also a subject of court proceedings. Among others, the Resolution of the Zinkiv District Court in the Poltava region of 27 April 272017 dismissed the claims for invalidation of the name change of a street in the village of Opishnia in the Poltava region, and the District Administrative Court in Odessa on 9 November 2017 rejected a lawsuit in on the change of street names and toponymy objects in the Odessa Oblast (Dekomunìzaciâ..., 2016; Zvìt Golovi..., 2017). The Babushkin District Court in Dnipropetrovsk (now Dnipro) is also known to have heard a lawsuit to cancel the mayor's order to rename the Stalingrad Heroes Street (Dekomunìzaciâ ..., 2016).

A common form of silent protest against the central government's imposition of total and mindless decommunization was some local governments' attempts to keep the old name by giving it a different interpretation. The trick was that in fact the new name was the same as the previous one, although formally it referred to a completely different person or event than before.

The implementation of decommunization in Ukraine has shown that the authorities and regional political elites are able to instrumentalize and manipulate the provisions on decommunization (Kutsenko 2020). In the event that decommunization changes became inevitable, attempts were made to maintain political neutrality when choosing new names by local governments. "Implementing the renaming policy, local authorities in the south east gave preference to Kievan Rus and Cossack legacy because such names are equally well acceptable by all strata of Ukrainians, regardless of ideology and electoral preferences, and no one will protest" (Gnatiuk, 2018, p. 10).

One of the key issues in assessing the "last" wave of decommunization of urban toponymy in Ukraine is to estimate its scale. According to the data of the Ukrainian Institute of National Memory, since 2015 the name change in Ukraine has affected an average of $3 \%$ to $5 \%$ of streets in cities, and in the east of the country - around 10\% (as in Kharkiv) (V'âtrovič (eds.), 2015). The numbers significantly varied in different cities. For example, out of 680 streets in Sloviansk, almost 130 (19\%) were changed, and in Vinnitsa, out of 840 street names approx. 140 (16\%) had to be renamed; in Kharkiv, out of 2,700 streets, about 285 names (10\%) had to be changed (V'âtrovič, 2015). According to the list of the Institute of National Memory, renaming 110 urbanonyms was necessary in Kiev (Males, 2016).

In the years 2014-2015, a total of 195 urban changes were made in Kiev. Nevertheless, of these changes, only 39 were implemented under the decommunization act. At the same time, public discussions were held on 126 new name proposals, as a result of which 4 newly proposed names were rejected, and other names for these sites were proposed (Males, 2016). In the following year, 2016, in 
Kiev, as part of the decommunization, 148 names of the city toponymy were changed (Dekomunìzaciâ ..., 2016).

By December 2016, as part of decommunization, 1,320 monuments to Lenin and 1,069 monuments to other Soviet leaders were dismantled; 32 towns and 955 villages were renamed (U V'âtroviča..., 2016). 51,493 toponymic sites were renamed, the most in the Kharkiv $(4,116)$, Poltava $(3,815)$ and Cherkasy $(3,646)$ oblasts, the least in Lviv $(9)$, Ivano-Frankivsk (76) and Ternopil (98) (Dekomunìzaciâ ..., 2016). In Mariupol, the boulevard with the original name llyicha was renamed twice. For the first time, on $28 \mathrm{Jan}$ uary 2016, the name was changed to Boyka Boulevard, a local politician and entrepreneur known for his pro-communist worldview, and already on 3 March to Nikopolski.

It is obvious that even after such a massive change of names as in Ukraine, this process is far from completely getting rid of remnants of post-communist nomenclature. For example, according to İ. Staren'kij and Â. Zajšlûk (2017), in Kamieniec Podolski, apart from the already renamed streets and alleys, another 38 urbanonyms are being decommunized. In other cities, the situation is similar, because usually only the most obvious names have been decommunized. For example, out of 74 city toponymy sites of Komsomolsk (now Horishni Plavni), only 5 were renamed by the city council in 2015 as part of decommunization (List Vikonavčogo..., 2016).

The positive result of decommunization was that the new street names became much less repetitive and more connected to the history of Ukraine. L. Males (2016) also notes that during the decommunization period the number of names associated with non-Ukrainian areas sharply fell, especially of those related to the geography or heroism of Russia. The new post-communist toponyms were given mainly local names, and where possible, historical names were restored.

\section{Conclusions}

Despite the long period that has passed since the loss of the dominant position of the communist ideology, the post-communist remnants in Ukraine were very numerous and important until 2014. Already a few years after the collapse of the USSR, decommunization of the naming of geographical sites in Ukraine slowly faded out, and then completely stopped. It was only the events of the Revolution of Dignity and Russia's armed aggression against Ukraine, including the annexation of Crimea, that forced the Ukrainian authorities to return to the subject of decommunization. In this situation, an attempt was made to cleanse the symbolic space of old communist names in one go and within a very short time.

In general, the policy of decommunization in Ukraine had much in common with the post-communist countries of Central Europe, including Poland. Nevertheless, there are significant differences. Firstly, the vast majority of renaming in Ukraine was conducted as part of the last wave, and not just after the fall of communism, as was the case in other post-communist countries. Secondly, decommunization in Ukraine was also a way of de-Russifying the symbolic space. Thirdly, pro-communist and leftwing political groups were surprised by the uncompromising policy of decommunization on the part of the central government and were unable to put up any noticeable resistance to the name changes.

The intensification of the toponymic policy of the central government led to growing contradictions and a certain loss of balance in relations with the authorities of some local governments. Some of these local governments have tried unsuccessfully to boycott, avoid or implement decommunization only formally and without enthusiasm. On the other hand, in Ukraine, the vast majority of geographical names that could be associated with the communist past have been removed.

It should be noted that after the active phase of 2014-2016, the process of decommunization of toponymy in Ukraine has already moved to the passive phase. However, there is no doubt that the problem itself has not been completely resolved. It may return to the agenda at any time as a tool of political struggle. It is still uncertain whether political changes associated with the right-wing forces losing power would not lead to another shift in the politics of remembrance, and some old communist names would not be restored.

\section{References}

Alderman D.H., 2002, Street names as memorial arenas: The reputational politics of commemorating Martin Luther King in a Georgia county, Historical Geography, 30, 99120.

Avioutskii V., 2006, Les révolutions de velours (Eng. The velvet revolutions), Armand Colin, Paris.

Âz'kovij A.A. (ed.), 2007, Ûgo-vostočnâ̂ Evropa: v èpohu kardinal'nyh peremeni (Eng. South-East Europe: In an age of cardinal change), Ves' Mir, Moskva.

Ciba V.M., 2017, «Dekomunìzaciầ» ì legìtimaciâ pravlâčoï elìti v Ukraïnì (Eng. „Decommunization” and legitimization of the ruling elite in Ukraine), Visnik Dnipropetrovs'kogo universitetu, 1, 152-171. 
Czepczyński M., 2008, Cultural Landscapes of Post-socialist Cities: Representation of Powers and Needs, Ashgate Publishing, Aldershot-Burlington.

Droguševs'ka Ì., 2017, Dekomunìzaciâ toponìmiï: koncepciâ povernennâ ìstoričnih nazv na kartu Ukraïni (Eng. Decommunization of toponymy: the concept of returning historical names to the map of Ukraine), Problemi bezperervnoi geografičnoï osviti ta kartografii, 26, 22-27.

Dymnicka M., Szczepański J., 2016, Polityki pamięci i tożsamości wobec (nie) chcianego dziedzictwa. Od Gdańska do Gdańzigu (Eng. Policies of memory and identity towards the (un) wanted heritage. From Gdańsk to Gdańzig), Przegląd Socjologiczny, 65(1), 81-100.

Dekomunizaciâ: pidsumki 2016 roku (Eng. Decommunization: results of 2016), 2016, Ukraïns'kij ìnstitut nacìonal'noï pam'âtì, Kiïv, http://www.memory.gov.ua/sites/default/ files/userupload/decomun-2016.jpg (accessed 30 December 2019).

Filon M.M., Borsuk Y.N., 2018, Origins and analysis of consequences of decommunization, Deržava ta Rehiony. Serîa: Ekonomika ta Pidpriêmnictvo, 6, 86-90.

Gnatiuk O., 2018, The renaming of streets in post-revolutionary Ukraine: regional strategies to construct a new national identity, AUC Geographica, 53(2), 119-136. doi: 10.14712/23361980.2018.13

Gricak Â., 2016, Dekomunizaciâ v Ukraïnì: pro et contra (Eng. Decommunization in Ukraine: pro et contra), https://www. youtube.com/watch?v=3ij93pfJJLM (accessed 31 March 2020).

Gurik M.l̀., 2016, Dekomunìzaciâ âk šlâh pobudovi ukraïnocentrists'koï modelì ìstoričnoï pam'âtì (Eng. Decommunization as a way to build a Ukrainian-centric model of historical memory), Aktual'nì problemi filosofii ta sociologiï, 11, 26-29.

Hałas E., 2004, Polityka symboliczna i pamięć zbiorowa. Zmiany nazw ulic po komunizmie (Eng. Symbolic policy and collective memory. Street name changes after communism), [in:] M. Marody (ed.), Zmiana czy stagnacja? Społeczeństwo polskie po czternastu latach transformacji (Eng. Change or stagnation? Polish society after fourteen years of transformation), Scholar, Warszawa, 128-152.

Hìtrova T., 2015, Dekomunìzaciâ âk ritoričnij diskurs ta džerelo formuvannâ ambìvalentnih smislìv u sučasnomu ìnformacìjnomu prostorì Ukraïni (Eng. Decommunization as a rhetorical discourse and a source of formation of ambivalent meanings in the modern information space of Ukraine), Obraz, 3, 60-67.

Jankowska M., 2013, Administracyjno-prawna problematyka zmiany nazewnictwa ulic Wrocławia w latach 1945-1946 (Eng. Administrative and legal issues of changing the nomenclature of streets in Wrocław in the years 1945-1946), Folia luridica Wratislaviensis, 2(1), 85-99.

Kędziora K., 2012, Nazewnictwo ulic Wrocławia w latach 1945 1994 (Eng. Nomenclature of Wrocław streets in the years 1945-1994), Instytut Pamięci Narodowej, Warszawa.

Kiridon A., 2017, Dekomunìzaciâ v Ukraïnì: priroda ta sutnìsnì harakteristiki procesu (Eng. Decommunization in Ukraine: nature and essential characteristics of the process), [in:] M.l. Mihajluca (ed.), Pivden' Ukraïni: etnoistoričnij, movnij, kul'turnij ta religijnij vimiri, vipusk 6, (Eng. South of Ukraine: ethnohistorical, linguistic, cultural and religious dimensions, issue 6), FOP Grìn' DS, Herson, 157-163.

Kita J., Nartonowicz-Kot M., 2012, Patroni łódzkich ulic (Eng. Patrons of Łódź streets) Księży Młyn Dom Wydawniczy, Łódź.

Konstitucìjne podannâ ŝodo vìdpovìdnostì Konstituciï Ukraïni (konstitucijnosti) Zakonu Ukraïni «Pro zasudžennâ komunističnogo ta nacional-socialističnogo (nacists'kogo) totalitarnogo režimiv ta zaboronu propagandi ïhn'oi simvoliki» vid 09.04.2015 No 317-VIII., 2015, (Eng. The constitutional motion to examine the compliance with the Constitution of Ukraine of the Act of Ukraine "On Condemnation of Communist and National Socialist (Nazi) Totalitarian Regimes and Prohibition of Propaganda of Their Symbols"), http://www.ccu.gov.ua/sites/default/ files/3_1919.pdf (accessed 31 March 2020).

Kozyrska A., 2016, Decommunisation of the Public Space in Post-Euromaidan Ukraine, Polish Political Science Yearbook, 45(1), 130-144.

Kuczabski A., Michalski T., 2014, Ukrainian Post-Communist Transformation: Causes, Consequences and Threats, Quaestiones Geographicae, 33(2), 171-180. doi: 10.2478/ quageo-2014-0024

Kutsenko D., 2020, Experience of implementing decommunization laws in Eastern Ukraine: a Kharkiv case, Journal of Geography, Politics and Society, 10(3), 55-64. doi: 10.26881/jpgs.2020.3.06

Kobčenko K., 2016, Dekomunìzaciâ v Ukraïnì: postkolonìal'nij kontekst (Eng. Decommunization in Ukraine: postcolonial context), Ukraïnoznavčij al'manah, 19, 66-70.

List Vikonavčogo komitetu Gorišn'oplavnivs'koï mis'koï radi Poltavs'koï oblastì №10-05/107 vìd 28.09.2016 r. (Eng. Letter of the Executive Committee of Horishni Plavni City Council of Poltava Region No 10-05/107, from 28 Sept. 2016), 2016, https://www.slideshare.net/DmytroKarpiy/ ss-66522963 (accessed 31 March 2020).

Łukowski W., Wojtaszczyk K.A. (eds.), 1996, Reform and transformation in Eastern Europe, Warsaw University Institute of Political Science, Warsaw.

Mälksoo M., 2018, Decommunization in Times of War: Ukraine's Militant Democracy Problem. Verfassungsblog: On Matters Constitutional, Verfassungsblog, http://www.verfassungsblog.de/decommunization-in-times-of-war-ukrainesmilitant-democracy-problem/. doi: 10.17176/20180109120812 (accessed 31 March 2020).

Males L.V., 2016, Dekomunìzaciâ stolicì: zmìni v urbanonìmiï (metodi, perši rezul'tati) (Eng. Decommunization of the capital: changes in urbanonymy (methods, first results)), Visnik Harkivs'kogo nacional'nogo universitetu ìmenì $V$. N. Karazina. Seriâ: Socìologičnì doslidžennâ sučasnogo suspil'stva: metodologîa, teoriâ, metodi, 36, 62-67.

Milczarek A., Nowak A.Z. (eds.), 2003, On the road to the European Union applicant countries' perspective, Warsaw University Centre for Europe, Warsaw.

Orlova T.V., 2010, Istoriâ novih mezaležnih deržav: Postsovieticum (Eng. History of the New Independent States: Postsovieticum), Vidavnictvo "Znannâ", Kiïv. 
Pìd čas "lenìnopadu" v Ukraïnì "zlâgli" ponad pivtisâči pam'âtnikiv (Eng. During the "Lenin's fall" in Ukraine "fell down" more than half a thousand monuments), 2014, Ekspres online 08.12.2014, http://expres.ua/ news/2014/12/08/121071-pid-chasleninopadu-ukrayinizlyagly-ponad-pivtysyachipamyatnykiv (accessed 21 October 2016).

Râbčuk M., 2016, Dekomunìzaciâ či dekolonìzaciâ? Ŝo pokazali polìtičnì diskusiï z privodu dekomunìzacìjnih zakoniv? (Eng. Decommunization or decolonization? What have the political debates about decommunization laws shown?), Naukovì zapiski İnstitutu političnih ì etnonacional'nih doslidžen' ìm. Ì. F. Kurasa NAN Ukraïni, 2, 104-117.

Râbenko S., Kogut A., 2017, Êvropejs'kì zakonodavčì praktiki dekomunizaciï: visnovki dlâ Ukraïni. Analitičnij zvìt (Eng. European legislative practices of decommunization: conclusions for Ukraine. Analytical report), Časopis, L'vìv.

Rose-Redwood R.S., 2008, From number to name: Symbolic capital, places of memory and the politics of street renaming in New York City, Social \& Cultural Geography, 9(4), 431-452.

Różycki B., 2018, Renaming urban toponomy as a mean of redefining local identity: the case of street decommunization in Poland, Open Political Science, 1(1), 20-31. doi: 10.1515/openps-2017-0004

Różycki B., 2019, Przemianowywanie ulic w Polsce 19892016. Charakterystyka zagadnienia (Eng. Renaming streets in Poland 1989-2016. Characteristics of the issue), [in:] A. Dubicki, M. Rekść, A. Sepkowski (eds.), W kręgu wyobrażeń zbiorowych. Polityka, władza, społeczeństwo (Eng. In the circle of collective ideas. Politics, power, society), Wydawnictwo Uniwersytetu Łódzkiego, Łódź, 145-172.

Staren'kij İ., Zajšlûk Â., 2017, Komunìzaciâ ta dekomunìzaciâ toponìmiï Kam'âncâ-Podil's'kogo (Eng. Communization and decommunization of Kamianets-Podilskyi toponymy), Misto: istoriâ, kul'tura, suspil'stvo, 1, 112-118. doi: 10.15407/mics2017.02.112

U V'âtroviča prozvìtuvali pro tisâču povalenih Lenìniv (Eng. In Viatrovych was told about a thousand overthrown Lenins), 2016, Ukraïns'ka pravda 27.12.2016, http://www. pravda.com.ua/news/2016/12/27/7131067/ (accessed 31 March 2020).

V'âtrovič V.M. (eds.), 2015, Dekomunizaciâ: ŝo ì čomu perejmenovuvati j demontuvati (Eng. Decommunization: what and why to rename and dismantle), Ukraïns'kij ìnstitut nacional'noï pam'âtì, Kiïv.

Vodotika S., Savenok L., 2017, Mìs'kij prostìr, dekomunìzaciâ ì problemi ìstoričnoï pam'âtì (Eng. Urban space, decommunization and problems of historical memory), Misto: istorîa, kul'tura, suspil'stvo, 2, 119-133. doi: 10.15407/ mics2017.02.119.

Wagińska-Marzec, M., 2017, Wokół zmian nazewnictwa ulic na Ziemiach Zachodnich i Północnych po 1945 r. (Eng. Around the changes in street names in the Western and Northern Territories after 1945), Rocznik Ziem Zachodnich, 1, 385-420. doi: 10.26774/rzz.178
Zakon Ukraïni «Pro zasudžennâ komunističnogo ta nacionalsocialističnogo (nacists'kogo) totalitarnogo režimiv ta zaboronu propagandi ïhn'oï simvoliki» (Eng. Law of Ukraine "On Condemnation of Communist and National Socialist (Nazi) Totalitarian Regimes and Prohibition of Propaganda of Their Symbols"), 2015, Vidomostì Verhovnoï Radi Ukraïni, 26, 1390.

Zvit Golovi Ukraïns'kogo ìnstitutu nacional'noï pam'âtì za 2017 rik (Eng. Report of the Chairman of the Ukrainian Institute of National Memory for 2017), 2017, Ukraïns'kij ìnstitut nacìnal'noï pam'âtì, Kiïv, http://www.memory.gov.ua/ sites/default/files/zvit_golovi_ukrayinskogo_institutu_nacionalnoyi_pamyati_2017.pdf (accessed 31 March 2020). 